\title{
University of Bradford Library Holding ISBN: 9783110686074
}

J B Priestly Libr, Richmond Rd

\author{
Bradford, GB BD7 1DP, United Kingdom
}

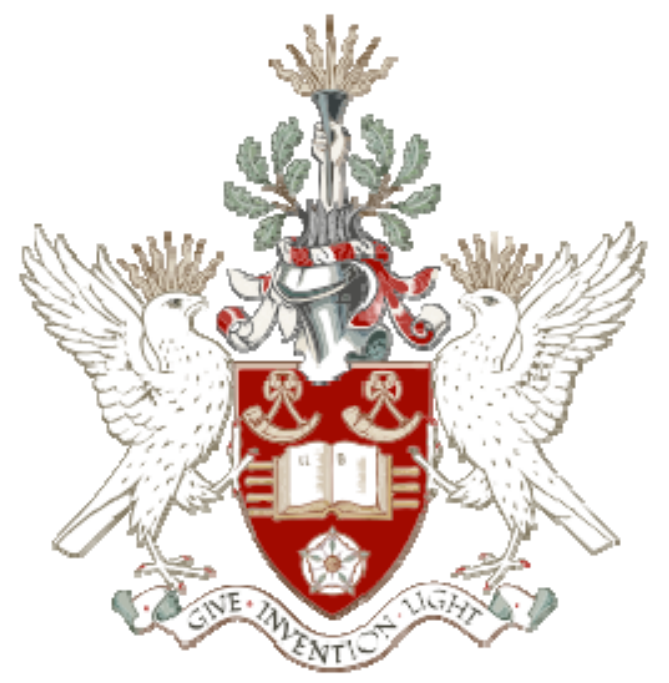

Book holding ISBN: 9783110686074

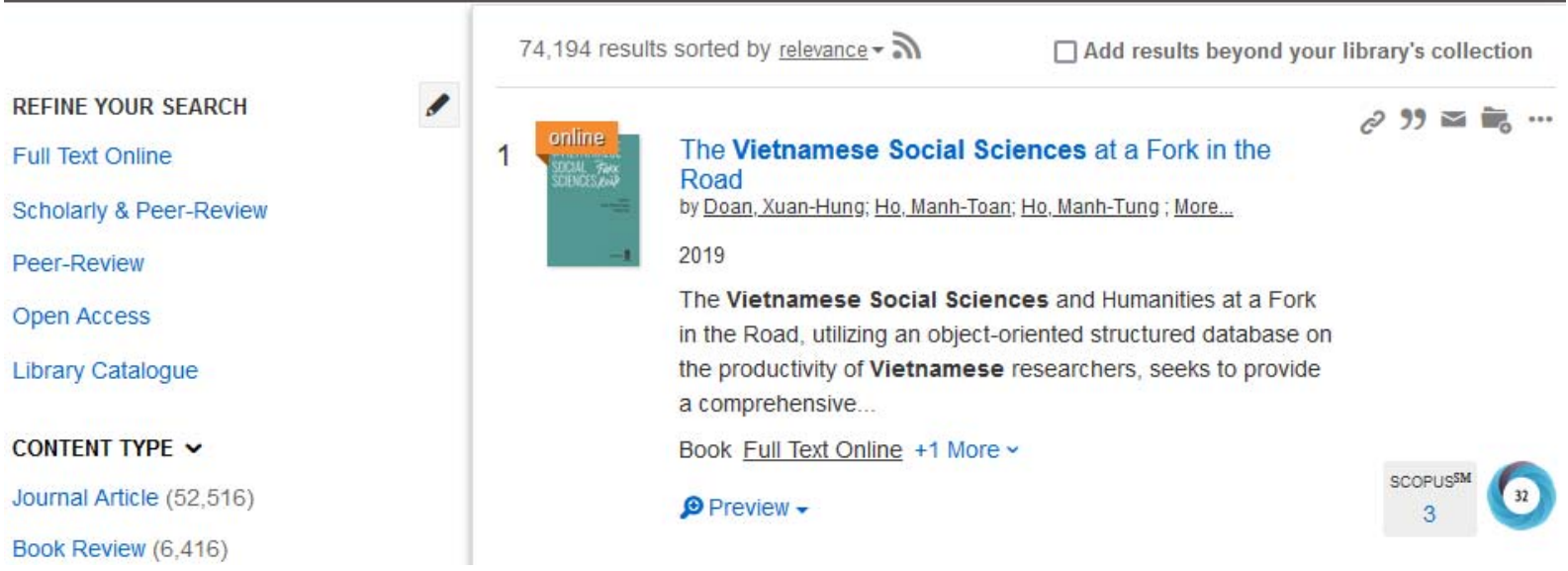


UNIVERSITY of

BRADFORD

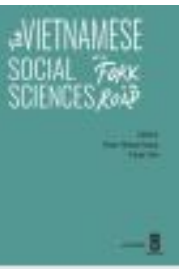

contents and more

Title

The Vietnamese Social Sciences at a Fork in the Road / ed. by Quan-Hoang

Vuong, Trung Tran.

Publication Warsaw; Berlin : Sciendo, [2019]

Info.

(C)2019

Available online

Full text access.

Linked

Titles:

Check if

Other

Formats

exist:

Description

Contents

Access

Conditions

Scope and

Content

Accessibility

System

Details

Language

Note

Finding

Aids

LC Subject

Added

Author
Title is part of eBook package: De Gruyter EBOOK PACKAGE

COMPLETE 2019 English 9783110610765

Title is part of eBook package: De Gruyter EBOOK PACKAGE

COMPLETE 2019 9783110664232 ZDB-23-DGG

Title is part of eBook package: De Gruyter EBOOK PACKAGE Economics,

Law \& Social Sciences 2019 ENG 9783110610130

Title is part of eBook package: De Gruyter EBOOK PACKAGE Social

Sciences 20199783110606485 ZDB-23-DSW

EPUB 9783110686326

print 9783110686074

1 online resource (244 pages)

text file PDF

Frontmatter -- Preface -- Abbreviations and acronyms -- About the authors -- List of Figures -- List of Tables -- Chapter 1. The debates and the long-awaited reform -- Chapter 2. Scientific publishing: a slow but steady rise -- Chapter 3. The fastergrowing fields -- Chapter 4. Economics: The trend-setting field -- Chapter 5.

Researchers who lead the trends -- Chapter 6. The question of quality -- Chapter 7. Scientific publishing: the point of no return -- Chapter 8 . The emerging business of science in Vietnam -- Closing remarks -- APPENDIX A. Complete transcription of interviews -- INDEX

restricted access http://purl.org/coar/access_right/c_16ec online access with authorization star

The Vietnamese Social Sciences and Humanities at a Fork in the Road, utilizing an object-oriented structured database on the productivity of Vietnamese researchers, seeks to provide a comprehensive overview of the development of Social Sciences and Humanities in Vietnam from 2008 to 2018. Quan-Hoang Vuong (Ph.D.,

Université Libre de Bruxelles) is the director of Centre for Interdisciplinary Social Research, Phenikaa University in Hanoi, Vietnam. He is chairman of the Vietnam chapter of the European Association of Science Editors and serves in the NAFOSTED Scientific Council on Basic Research in the Social Sciences and Humanities (2019-2021). Dr. Vuong has published more than 120 academic articles, and book chapters in about 50 refereed journals and books by such publishers as Elsevier, Inderscience, Nature Publishing Group, Springer, Praeger, Wiley, World Scientific, etc. Trung Tran is an Associate Professor of Mathematics Education and works at Vietnam Academy for Ethnic Minorities. He is a member of the Vietnam chapter of The European Association of Science Editors (EASE), a leader of the Vietnamese Science Editors (VSE) Team, and a chairman of Editor's Board of Journal of Ethnic Minorities Research (ISSN: 0866-773X).

The Library makes every effort to purchase ebooks in a format that is accessible to everyone. If the format of this ebook is not accessible to you, please mail libaccessiblity at bradford.ac.uk and the Library will attempt to make alternative arrangements.

Mode of access: Internet via World Wide Web.

In English.

Description based on online resource; title from PDF title page (publisher's Web site, viewed 21. Jun 2021)

Available in electronic full text to members of the University via the Library web catalogue.

SOCIAL SCIENCE / General.

Doan, Xuan-Hung, contributor. Contributor. https://id.loc.gov/vocabulary. $\underline{\text { relators/ctb }}$ 
Ho, Manh-Toan, contributor. Contributor. https://id.loc.gov/vocabulary. /relators/ctb

Ho, Manh-Tung, contributor. Contributor. https://id.loc.gov/vocabulary. /relators/ctb

Hoang, Khanh-Linh, contributor. Contributor. https://id.loc.gov/vocabulary. /relators/ctb

Hoang, Phuong-Hanh, contributor. Contributor. https://id.loc.gov /vocabulary/relators/ctb

La, Viet-Phuong, contributor. Contributor. https://id.loc.gov/vocabulary. /relators/ctb

Le, Thu-Hien T., contributor. Contributor. https://id.loc.gov/vocabulary /relators/ctb

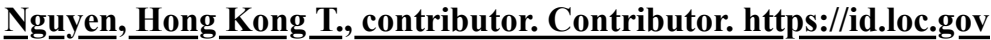
/vocabulary/relators/ctb

Nguyen, Hong-Kong $T$., contributor. Contributor. https://id.loc.gov /vocabulary/relators/ctb

Nguyen, Minh-Hoang, contributor. Contributor. https://id.loc.gov /vocabulary/relators/ctb

Nguyen, Phuong-Tram T., contributor. Contributor. https://id.loc.gov /vocabulary/relators/ctb

Nguyen, Thu-Hang T., contributor. Contributor. https://id.loc.gov /vocabulary/relators/ctb

Nguyen, Tien-Trung, contributor. Contributor. https://id.loc.gov/vocabulary. /relators/ctb

Pham, Hiep-Hung, contributor. Contributor. https://id.loc.gov/vocabulary. /relators/ctb

Tran, Trung, contributor. Contributor. https://id.loc.gov/vocabulary. /relators/ctb

Tran, Trung, editor. Editor. http://id.loc.gov/vocabulary/relators/edt Trinh, Phuong-Thao T., contributor. Contributor. https://id.loc.gov /vocabulary/relators/ctb

Vu, Thi-Hanh, contributor. Contributor. https://id.loc.gov/vocabulary. /relators/ctb

Vuong,Quan-Hoang, contributor. Contributor. https://id.loc.gov/vocabulary. /relators/ctb

Vuong,_uan-Hoang, editor. Editor. http://id.loc.gov/vocabulary/relators/edt Vuong, Thu-Trang, contributor. Contributor. https://id.loc.gov/vocabulary /relators/ctb

No. 
* Permalink:

https://go.exlibris.link/mSyDvJfg

(Accessed: September 19, 2021) 